\title{
Knowledge and practices on gynecological care for medical students: breast self-exam and Pap test
}

\begin{abstract}
Objective: To evaluate the knowledge and practices of students from the 1 st to 3rd year of the medical course of the State University of Pará on breast self-examination and prevention of cervical cancer.

Method: This is an epidemiologic, quantitative and descriptive study in which data were collected with a questionnaire formulated by authors and it was applied to students. The chi-square test and the G-test were used in data statistic.

Results: There was a higher prevalence of single women (97.7\%), aged 20 to 21 years old $(40 \%)$, who never became pregnant $(97.7 \%)$. Evaluating the results of Pap smear, $89.2 \%$ of students reported knowing about the exam, and more than a half were never submitted to it $(67.7 \%)$. In the analysis of Breast Self-Examination, $97.7 \%$ of the population studied was conscious of the test, and $99.2 \%$ correctly know its purpose. The university $(29.9 \%)$ and television $(28.3 \%)$ are the major knowledge providers about the exam. $53.8 \%$ did not know the correct recommendation of when to start selfexamination of the breasts.

Conclusion: Even most of the students in the 1st to the 3rd year of the medical course, who are familiar with the exams, present a lack of updated and more specific information regarding pre-examination care, the age group in which each one is indicated and the way in which they are performed, since much of the information is obtained through teachers and not in accordance with national and international guidelines.
\end{abstract}

Keywords: medical, students, breast self, examination, papanicolaou, test, national, women

\section{Introduction}

Currently, cancer is highly explored and seen as a major public health problem in the world. In Brazil, among different types of cancer that affect women, breast cancer and cervical cancer are the most frequent disturbances among gynecological cancers. ${ }^{1}$ Although there is a very high rate of cancer incidence. The cancer mortality reduction was being observed; especially in young women. ${ }^{2}$ Authors relate this fact with an increase in early neoplastic lesions detection as well as treatment efficiency. It became possible through breast cancer screening programs such as mammography which cause a breast cancer mortality reduction and an early lesion detection in subclinical forms, what happens primarily in European countries. ${ }^{3}$

Sometimes, women are encouraged to do breast self-examination as a form of early detection. It shows the importance of women active participation that receives specific guidance about exam techniques. Despite this, Thomas et al., ${ }^{4}$ concluded that breast selfexamination did not cause an increase in breast cancer mortality rates and only increases unnecessary biopsies number with a benign result. However, there are benefits related to a method that can predict a presence of small tumor or lesions still confined in the mammary gland. Therefore, it can be advised breast self-examination may be done always when women feel comfortable for this. Early detection of small tumors predict a less violent and painful treatment and, unlike this, late diagnosis decreases the chances of cure and it is responsible for increased mortality rates. ${ }^{5-7}$

About cervical cancer, high incidence corresponds to women between thirty to thirty-nine years old. Pap smear screening for cervical cancer begins at twenty-five years old and should be done
Volume 8 Issue I - 2019

\author{
Fernando Mateus Viégas Brandão,' Gisele \\ Moura de Oliveira Leite,' Elisa Maria Novaes \\ Barros,' Camila Furtado Leão,' Mariseth \\ Carvalho de Andrade, ${ }^{2}$ Nara Macedo \\ Botelho, ${ }^{3}$ Vanessa Novaes Barros ${ }^{4}$ \\ 'Faculty of Medicine, Universidade Estadual do Pará, Brazi \\ 2Departament of Epidemiology, Fundação Santa Casa de \\ Misericórdia do Pará, Brazil \\ ${ }^{3}$ Departament of Gynecology and Obstetrics, Universidade \\ estadual do Pará, Brazi \\ ${ }^{4}$ Professor at Estácio Castanhal faculty, Brazil
}

Correspondence: Vanessa Novaes Barros, Professor at Estácio Castanhal faculty, Pará, Brazil, Email barros.novaes@hotmail.com

Received: December 12, 2018 | Published: January 08, 2019 annually until two negative results are obtained. After this, screening can be done every three years. The main risk factor is associated with an infection by Human Papilloma Virus (HPV) and its prevalence occurs before twenty-five years old when the development of intraepithelial lesions can begins (because of it, screening begins at this age).These lesions need a specialized follow-up because they are cancer-related cellular changes, although major of them present spontaneous regression. ${ }^{8-10}$

Primary care for women health may be based on humanization and prevention. Thus, it is indispensable a good guidance given to patients about the importance of undergoing a Pap smear screening for cervical cancer and breast self-examination. ${ }^{5}$ However, the reality is different from what is expected and it is strongly related to education level. Sometimes women do not take these exams because do not know how to do or think it is not really necessary. ${ }^{11}$ Therefore, it is important evaluates the situation of medical students about knowing and practicing this specific health care for the purpose of know if what is learned at the university has been done for their own health and if they are able to guide others. From this, should be done interventions with these students in order to enrich the information and to improve quality of life of those who they will handle in academic life.

\section{Methods}

This is an epidemiologic, quantitative, descriptive study with a cross-sectional design; performed at Universidade do Estado do Pará. All procedures were according to ethical standards of the institutional and/or National Research Committee according to Helsinki Declaration and its later amendments or comparable ethical standards. The study received ethical approvals from the Human Subjects 
Review Committee of Universidade do Estado do Pará (UEPA) under the protocol 1.781.117. All participants provided written consent to participate. The research data consisted of 130 female students from first to the third year of medicine course that agreed to participate in the study. The casuistry was calculated by Biostat 5.0. Program. After ethical committee's approval, students from first to the third year of UEPA's medical course were invited to participate in the research in a period from April to May of 2017. Those who have signed the consent were able to fill the questionnaires. All of the female students from first to the third year of Universidade do Estado do Pará medical course that agreed to participate are included in the research. Students who had refused to participate were excluded. Questionnaires were applied to evaluate variables such as age, marital status, previous pregnancy and the knowledge about breast self-exam and Pap smear screening for cervical cancer. Those questionnaires were based on Neto $\& \mathrm{Paz}^{11} \&$ Souza et al., ${ }^{12}$ and were filled by the students themselves. Correction of the answers was according to Basic Attention Registry for the Control of Uterine and Cervical Cancers ${ }^{5}$ and to Brazilian Guidelines for the Screening of Cervical Cancer. ${ }^{13}$

The statistical analyses were performed using Biostat 5.0 Program. The chi-square test was used to evaluate the significance of associations between categorical variables and G-test for continuous variables.

\section{Results}

Data analysis of 130 participants showed that the average age was $20.1( \pm 2.3)$ years old. Only $2.3 \%$ were married and $97.7 \%$ never had any previous pregnancy (Table 1 ).

Table I Students' clinical-epidemiological profile from Ist to 3 rd year of Universidade do Estado do Pará medical course, from April to May of 2017

\begin{tabular}{lll}
\hline General data & $\begin{array}{l}\text { Absolute number } \\
\text { (AN=130) }\end{array}$ & Percentage \\
\hline Age (years) & 12 & \\
16 a 17 & 44 & $9,2 \%$ \\
18 a 19 & 52 & $33,8 \%$ \\
20 a 21 & 22 & $40 \%$ \\
$>=22$ & $20.1 \pm 2.3$ & $16,9 \%$ \\
Media \pm Standard deviation & & \\
Previous pregnancy & 3 & \\
Yes & 127 & $2,3 \%$ \\
Not & & $97,7 \%$ \\
Marital status & 127 & \\
Single & 3 & $2,3 \%$ \\
Married & & \\
*P 0.000 I Chi-square test & & \\
Source: Research's Record &
\end{tabular}

About Pap smear screening for cervical cancer, 89.2\% answered that knew the exam, but only $4,6 \%$ knew about pre-examination care. $32.3 \%$ of participants had already undergone a Pap smear test and $19 \%$ of them had taken the exam four or more times. When questioned about the importance of doing the exam, $84.6 \%$ answered correctly, but only 3,8\% showed a right knowledge about being submitted to a Pap smear test (Table 2).
Table 2 Knowledge about Pap smear screening for cervical cancer of students from Ist to 3rdyear of Universidade do Estado do Pará medical course from April to May of 2017

\begin{tabular}{lll}
\hline Questions asked & $\begin{array}{l}\text { Absolute number } \\
(\mathrm{AN}=130)\end{array}$ & Percentage
\end{tabular}

Have you ever heard about Pap

smear screening for cervical cancer?

$\begin{array}{lcc}\text { Yes* } & 116 & 89,2 \% \\ \text { Not } & 14 & 10,8 \%\end{array}$

Have you ever submitted to Pap smear screening for cervical cancer?

Yes

$32,3 \%$

Not*

The frequency of submission to Pap smear screening for cervical cancer $(\mathrm{AN}=42)$

One

Two

Three

Four or more

Pre-examination care

Wrong / Do not Know / Does not report*

Confused

Partially

Right

Do you know about the importance of this exam?

Right*

$84,6 \%$

Wrong

Do not know

Knowledge about ideal frequency to be submitted to Pap smear screening for cervical cancer

$\begin{array}{lcc}\text { Partially* } & 91 & 70,0 \% \\ \text { Wrong } & 19 & 14,6 \% \\ \text { Right } & 5 & 3,8 \% \\ \text { Do not know } & 15 & 11,5 \%\end{array}$

\section{$*_{p}<0.000$ I Chi-square test}

Source: Research's Record

In relation to breast self-examination, $97.7 \%$ of the women had heard about it and the main knowledge provider was University (29.9\%) and Media (28.3\%). 99.2\% answered correctly about the exam purpose, however, $53,8 \%$ answered incorrectly about the moment when this exam should be started. When the researchers questioned the reason for not to take the exam, $32.94 \%$ said it is not necessary, $25.9 \%$ did not say the reason and $8.2 \%$ assumed laziness or neglect as justification (Table 3 ). 
Table 3 Knowledge about breast self-examination of students from Ist to 3rdyear of Universidade do Estado do Pará medical course from April to May 2017

\begin{tabular}{|c|c|c|}
\hline Questions asked & $\begin{array}{l}\text { Absolute number } \\
(\mathrm{AN}=130)\end{array}$ & Percentage \\
\hline \multicolumn{3}{|l|}{$\begin{array}{l}\text { Have you ever heard about } \\
\text { breast-self examination? }\end{array}$} \\
\hline Yes* & 127 & $97,7 \%$ \\
\hline Not & 3 & $2,3 \%$ \\
\hline \multicolumn{3}{|c|}{$\begin{array}{l}\text { Knowledge provider about the } \\
\text { exam }(\mathrm{AN}=127)\end{array}$} \\
\hline University* & 38 & $29,9 \%$ \\
\hline Media* & 36 & $28,3 \%$ \\
\hline Internet & 16 & $12,6 \%$ \\
\hline Mother & 15 & $11,8 \%$ \\
\hline Doctor & 14 & $11,0 \%$ \\
\hline Campaigns & 10 & $7,9 \%$ \\
\hline School & 5 & $3,9 \%$ \\
\hline \multicolumn{3}{|c|}{$\begin{array}{l}\text { Knowledge about the purpose of } \\
\text { the exam }\end{array}$} \\
\hline Right** & 129 & $99,2 \%$ \\
\hline Did not answer & 1 & $0,8 \%$ \\
\hline \multicolumn{3}{|c|}{$\begin{array}{l}\text { Knowledge about the moment } \\
\text { when this exam should be started }\end{array}$} \\
\hline Wrong* & 70 & $53,8 \%$ \\
\hline Do not know & 23 & $17,7 \%$ \\
\hline Right & 37 & $28,5 \%$ \\
\hline \multicolumn{3}{|c|}{$\begin{array}{l}\text { Reason for not to take the exam } \\
(\mathrm{AN}=85)\end{array}$} \\
\hline Did not answer* & 22 & $25,9 \%$ \\
\hline Do not know how to do & 9 & $10,6 \%$ \\
\hline Negligence / Sloth & 7 & $8,2 \%$ \\
\hline Think it is not necessary & 28 & $32,94 \%$ \\
\hline Forgetfulness & 10 & $11,80 \%$ \\
\hline Other & 9 & $10,6 \%$ \\
\hline
\end{tabular}

${ }^{*} \mathrm{p}<0.000$ I Chi-square test, ${ }^{* *} \mathrm{p}<0.000$ I G-test

Source: Research's Record

\section{Discussion}

Among the students from 1 st to 3 rd year of Universidade do Estado do Pará medical course, age range and marital state agree to others researches found in literature, that also make an investigation on university women groups. ${ }^{11,14} \mathrm{~A}$ low pregnancy rate in casuistry studied can be explained by a women low age prevalence and high education level, as demonstrated by Miranda-Ribeiro e Garcia (2016)..$^{15}$

It was observed a high knowledge about Pap smear that could be seen in general women population, without being from health academic area, as demonstrated by Mendes et al., ${ }^{16}$ Although, there is an extremely low knowledge concerning pre-examination care.
Among the frequently wrong answers, stands out a very common recommendation by gynecologists: sexual abstinence some days before the exam. However, Brazilian Health Ministry ${ }^{5}$ affirmed, even usual, the recommendation just justified when was used condoms with spermicidal lubricants, because in practice, spermatozoids presence does not compromise microscopy evaluation and this information was not reported by participants. Other relevant data is the high women percentage that confounds the answer about Pap smear preexamination care, in other words, answered as if the question refers about the pre-examination care that professionals have to take to patient security, and not self-care. It is important to evaluate from the perspective of Chitto Gauer et al. ${ }^{17}$ who demonstrates that caregivers many times neglect self-care in detriment of others. The statistic high level of women who never were submitted to a Pap smear found in this research is not a negative result. National Institute of Cancer ${ }^{13}$ recommends that this exam has to be done only by women from 25 to 64 years old and shows that are low evidence about the importance of screening outside this age group. In this way, the data from this research is not worrisome, since just $16,9 \%$ of women are on age range equal or over 22 years old. In contrast, this data disagree with others studies found in the literature described by Okamoto et al., ${ }^{18}$ whose study shows that $88 \%$ women from health academic area had already done Pap smear, although women are from the same age range as this research. When the importance of being submitted to Pap smear was questioned, the majority of participants answered correctly. It demonstrates a satisfactory knowledge level among the studied population, which agree with Souza et al., ${ }^{12}$ who shows that $86 \%$ of interviewed students from health area answered correctly about the exam importance.

A very limited part of the students answered correctly the question about ideal frequency to be submitted to a screening for cervical cancer. However, $70 \%$ do not relate that after two consecutive negative results the exam has to be repeated only every 3 years. This recommendation is from National Institute of Cancer $^{13}$ and shows that being submitted to unnecessary exams do not bring benefits for women. Before the evaluation of breast-self cancer examination results, it is necessary to remember that clinical randomized trials did not demonstrate reduced breast cancer mortality by means of self-examination. In addition, it was demonstrated that it culminates with an increase of unnecessary biopsies number. ${ }^{19}$ Brazilian Heath Ministry ${ }^{5}$ recommends that women perform breast self-palpation with no specific technique just to recognize some possible change and know their body better whenever they feel comfortable with doing this examination. Despite this, many recent papers still indicate the systematized practice of breast self-examination used as an efficient instrument to help breast cancer early diagnosis. ${ }^{20,21}$

Analyzing the results of breast self-examination, it was found that most of the interviewed knew the exam and can say its finality. University and television are the major knowledge providers. Many studies had demonstrated similar data around the world. ${ }^{11,22,23}$ It shows the high importance of communication media to propagate healthcare information. When asked about the reason to do not do the breast self-exam, 32,9\% said it is not necessary, however, the researchers did not found in the literature any similar data. The hypothesis is that since most of them knew the exam only in university, they received orientations according to the new international guidelines that do not recognize the exam as a diagnoses investigative strategy. This data does not agree with others as Nde et al., ${ }^{23} \&$ Neto e Paz ${ }^{11}$ who shows forgetfulness was the most common factor to do not do this exam. It is 
worth noting that, although most of women students of medical course had heard about both exams, they often receive the information but is not able to analyze critically based on scientific evidence and put into practice. It may be related to the way that knowledge is passed into universities, often limited to demonstrate only the exams importance or technique of them and no additional information about frequency and pre-examination care. It is very important an approach change of women's health issues so that students can aggregate knowledge in the best way in order to put into practice for their own health and patients' health.

\section{Conclusion}

This study concludes that, although a large part of women students of medical course has some knowledge about Pap smear and Breast cancer self-examination. It still lacks more updates and specific information, mainly about Pap pre-examination care, age-range that the exams should be started and the way they should be performed. It possible happens because information is not obtained in accordance with national and international guidelines.

\section{Acknowledgments}

We appreciate the financial support of Conselho Nacional de Desenvolvimento Científico e Tecnológico $(\mathrm{CNPq})$ directed to the present research on public notice $\mathrm{N}^{\circ} 030 / 2016$ of the State University of Pará.

\section{Conflicts of interest}

The author declares there are no conflicts of interest.

\section{References}

1. INCA. Estimativa 2014: Incidência de câncer no Brasil. 2014.

2. Autier P, Boniol M, La Vecchia C, et al. Disparities in breast cancer mortality trends between 30 European countries: retrospective trend analysis of WHO mortality data base. Bmj. 2010;341:c3620.

3. Senkus E, Kyriakides S, Ohno S, et al. Primary breast cancer: ESMO Clinical Practice Guidelines for diagnosis, treatment and follow-up. Ann Oncol. 2015;22(Supply 5):v8-v30.

4. Thomas DB, Gao DL, Self SG, et al. Randomized trial of breast selfexamination in Shanghai: methodology and preliminary results. J Natl Cance Inst. 1997;89(5):355-365.

5. Controle dos cânceres do colo do útero e da mama. Brasil: Caderno de Atenção Básica; 2013. 13 p.

6. Brito LMO, Chein MBC, Brito LGO, et al. Conhecimento, Prática e atitude sobre o autoexame das mamas de mulheres de uma cidade do Nordeste do Brasil. Rev. Bras. Ginecol. Obstet. 2010;32(5):241-246.

7. Rodrigues JD, Cruz MS, Paixão AN. Uma análise da prevenção do câncer de mama no Brasil. Revista Ciência \& Saúde Coletiva. 2015;20(10):3163-3176.
8. Diretrizes brasileiras para o rastreamento do câncer do colo do útero. Brasil. 2011.118 p.

9. Ações de enfermagem para o controle do câncer: uma proposta de integração ensino-serviço. Brasil. 2008. 624 p.

10. Maeda TC, Alves AP, Silva SR. Conhecimento de mulheres idosas sobre o exame de papanicolau. Cienc Cuid Saude. 2012;11(2):360-367.

11. Neto JDV, Paz LB. Autoexames das Mamas: conhecimento e prática entre as estudantes de medicina privada de ensino de Teresina, PI Revista Interdisciplinar Novapi. 2011;4(2):68-73.

12. Souza GDS, Simões ALB, Sousa MF, et al. Adesão e conhecimento de discentes de enfermagem sobre o exame papanicolau: uma proposta de abordagem crítico-social. Arq Cienc Saúde Unipar. 2015;19(1):19-23.

13. Diretrizes brasileiras para o rastreamento do câncer do colo do útero. Brasil. 2016.116 p.

14. Almeida MHL, Carneiro TF, Alberti LR. Nível de conhecimento das estudantes de medicina acerca do HPV e sua principal decorrência, o câncer de colo de útero. Urominas. 2015;30(1):30-36.

15. Miranda Ribeiro A, Garcia RA. Transições da fecundidade no Brasil: uma análise à luz dos diferenciais por escolaridade. Brasil: Censo Demográfico; 2018. 17 p.

16. Mendes LC, Silveira CF, Silva SR. Conhecimento de mulheres a respeito do exame de papanicolau e do autoexame das mamas. Rev Enferm Atenção Saúde. 2013;2(3):4-17.

17. Gauer GJC, Franco RS, Zogbi H, et al. Estratégias dos profissionais de saúde para cuidar dos que cuidam. Rev Bioet. 2006;14(2):171-180.

18. Okamoto CT, Faria AAB, Sater AC, et al. Profile of Knowledge on HPV and its Prevention among Students at a Private University in Curitiba. Rev Bras Educ Med. 2016;40(4):611-620.

19. Kösters JP, Gotzsche PC. Regular self examination or clinical examination for early detection of breast cancer. Cochrane Database Syst Rev. 2003;2:CD003373.

20. Romanoff A, Constant TH, Johnson KM, et al. Association of Previous Clinical Breast Examination with Reduced Delays and Earlier-Stage Breast Cancer Diagnosis among Women in Peru. JAMA Oncology. 2017;3(11):1563-1567.

21. Kutlu R, Biçer Ü. Evaluation of Breast Cancer Risk Levels and Its Relation with Breast Self-Examination Practices in Women. Eur J Breast Health. 2017;13(1):34-39.

22. Gomes LMX, Alves MC, Santos TB, et al. Conhecimento e prática do autoexame das mamas por acadêmicas de enfermagem. Rev Cubana Enfermer. 2012;28(4):465-473.

23. Nde FP, Assob JCN, Kwenti TE, et al. Knowledge, attitude and practice of breast self-examination among female undergraduate students in the University of Buea. BMC Res Notes. 2015;8(1):43. 